\title{
The Distribution and Load Duration Curves of Selected Pollutants in River Ekulu Enugu urban, Nigeria
}

\author{
${ }^{1 *}$ Butu, A.W. $\quad{ }^{2}$ Ubachukwu, N.N $\quad{ }^{3}$ Emeribe, N.C. $\quad{ }^{4}$ Dadan-Garba, A. $\quad{ }^{5}$ A.A Bichi \\ 1. Department of Geography, Nigerian Army University Biu, Nigeria \\ 2. Nigerian Tulip International College Abuja, Nigeria \\ 3. National Centre for Energy and Environment, Energy Commission of Nigeria, University of Benin, \\ Benin City, Nigeria \\ 4. Department of Geography, Nigerian Defence Academy Kaduna, Kaduna State, Nigeria \\ 5. Department of Geography, Federal University Gusau, Nigeria
}

\begin{abstract}
The study investigated the seasonal distribution and load duration curves of selected pollutants in River Ekulu, Enugu urban, Nigeria. Selected water quality parameters such as turbidity, total suspended solid, iron, magnesium, phosphate, and total coliform were analyzed using standard methods. Data were collected between October 2015 and September, 2016. Stream flow measurement was undertaken for 12 calendar months using the Velocity-Area Method. The result shows very high concentration of the selected pollutants in River Ekulu when compared with the WHO maximum permissible Limit. Turbidity recorded mean value of 84.6NTU. Average concentration of $143.6 \mathrm{mg} / 1,1.2 \mathrm{mg} / 1,4.2 \mathrm{mg} / 1,3.1 \mathrm{mg} / \mathrm{l}$ and $142.2 \mathrm{CFU} / 100 \mathrm{ml}$ were recorded for $\mathrm{TSS}, \mathrm{Fe}, \mathrm{Mg}$, $\mathrm{PO}_{4}{ }^{3-}$ and TCC respectively. Results of load duration curve show that the actual load of these pollutants exceeds their permissible limits. Deterministic relationship between flow and pollutant distributions at 0.05 level of significance shows high level of correlation. Turbidity, TSS, Fe, $\mathrm{Mg}, \mathrm{PO}_{4}{ }^{3-}$ and $\mathrm{TCC}$ yielded coefficient of determination values of $0.92,0.93,0.90,0.97,0.98$ and 0.77 respectively. High values of Turbidity, TSS, iron, magnesium, phosphate and TCC observed from the study especially at flow peak are indications of expanding/unplanned residential and commercial land uses. The high concentration of these pollutants could be deleterious to human health if the water from the River is continuously consumed without proper treatment. The study, therefore, recommends proper waste management practices. There is also need to enact and enforce laws on effluent treatments at slaughter houses before discharge into water bodies.
\end{abstract}

Keywords: Flow duration curve, pollutant load, urbanization, water, quality

DOI: $10.7176 / \mathrm{JRDM} / 64-05$

Publication date: April $30^{\text {th }} 2020$

\section{Introduction}

Water quality refers to the chemical, physical, biological and radiological characteristics of water (Diersing, 2009). In Nigeria one of the greatest challenges of environmental sustainability and economical development has been the problem of surface water pollution (Ezemonye, 2009). Surface water contributes significantly to environmental degradation and caused serious flooding in most parts of the cities, proliferation of insects, aesthetic nuisance, bad odour, among others (Osibanjo, Daso and Gbadebo, 2011) Pollution of freshwater is an increasing problem, as there are million cases of water-related diseases annually. It is estimated that 801,000 children younger than 5 years of age perish from diarrhea each year, mostly in developing countries. This amounts to $11 \%$ of the 7.6 million deaths of children under the age of five and means that about 2,200 children are die every day as a result of diarrheal diseases (Liu, 2012). Butu and Sadiq (2016) are of the view that water pollution occurs when unwanted substances with potential to threaten human and other natural systems enter it. The problem of water pollution is exacerbated by the fact that the leading cause of human mortality all over the world is water related ailments and the fact that in Africa, above $50 \%$ of every reported case of hospitalization has been tied to water related problems (Omole and Ndambuki, 2014). At the heart of the world's water problems, however, is the failure to provide even the most basic water services for billions of people and the devastating human health problems associated with that failure (Gleik, 2002).

In Nigeria available reports show that gross contamination of most river bodies across the nation are linked to discharge of industrial effluent, sewage and agricultural waste and other diffuse sources. Ezigbo (1989) and Amadi (2010) observe that changes in water of rivers are usually anthropogenic via domestic, industrial and agricultural discharge which may in turn result to degradation of the aquatic system. Amadi (2012) also observe that most of the surface water bodies in Nigeria are polluted because they serve as disposal sites for different kinds of wastes. Most surface water sources are bacteriologically polluted in Nigeria. Thus, Ezigbo and Nzeanyim (1993) are of the view that coliform counts of over 1800 per $100 \mathrm{ml}$ of water is recorded in several rivers or streams in southern Nigeria. The major factors affecting the bacteriological quality of surface are discharge from sewage works and runoff from informal settlements. Population increase in urban centers has been implicated to be the most important cause of stream health deterioration and one of the biggest challenges 
facing watershed managers in developing countries (Ogbomida and Emeribe, 2013). The population increase in urban areas affects the patterns of ecologic structure and function by altering the physical landscape, increasing imperviousness, and changing channel morphology (Paul and Meyer 2001; Sponseller, Benfield and Valett, 2001; Walsh, Sharpe, Breen and Sonneman, 2001; Kearns, Kelly, Karter and Resh, 2005; Chadwick, Aobberfuhl, Benke, Huryn, Suberkropp and Thiele, 2006; Walsh, 2006). Butu, Bello, Atere and Emeribe (2019) also attributed the abundance of heavy metals and other chemical pollutants in aquatic systems to anthropogenic activities and geologic process. They are also of the view that population explosion and increased industrial activities have contributed to the addition of unhealthy chemical substances into the ecosystem especially water bodies thereby making man vulnerable to infection.

Urban storm water enters creeks and rivers more readily from impervious surfaces and can increase the flashiness of the flow regime. Urban runoff can also affect water chemistry by changing levels of heavy metals and nutrients like phosphorus and nitrogen (Porcella and Sorenson, 1980; Morse, Huryn and Crona, 2003). These impacts from anthropogenic activities in urban areas can cause changes in the biological communities of the stream ecosystems (Morse et al., 2002, Chadwick et al. 2006; Voelz, Zuelliz, Shieh and Ward, 2005; Walsh, 2006). Nigeria has witnessed rapid urban growth since the $19^{\text {th }}$ century at a growth rate of $5.8 \%$ per annum (NUDP, 2004). Similarly, improper management of vast amount of wastes generated by various unplanned anthropogenic activities and the unprecedented urbanization in the country has gradually led to the deterioration of water in recent years (Chindah, Braide and Sibendu, 2004; Emongor, Nkegbe, Kealdtswe, Koorapetse, Samkwase and Keikantswe, 2005; Osibanjo, et al., 2011). Enugu town is the capital of Enugu state; rapid urbanization and urban development with attendant environmental problems have continued in Enugu and have also created serious pressure on water availability and quality (Ezenwaji, Eduputa and Uwadiegwu, 2014). Enugu metropolis, being one of the major industrial hubs in south eastern Nigeria also hosts hundreds of industries, and hundreds of thousands of residential institutions and households with attendant pollution activities on continuous increase. The aim of this study is therefore to assess the seasonal concentration of some pollutants in River Ekulu which is a major receptor of urban storm water.

\section{The Study Area}

The study area is River Ekulu in Enugu Metropolitan City. The city is located approximately between latitude $6^{0}$ $30^{\prime} \mathrm{N}$ and $6^{0} 40^{\prime} \mathrm{N}$ of the equator and longitude $7^{0} 20^{\prime} \mathrm{E}$ and $7^{0} 35^{\prime} \mathrm{E}$ of the Greenwich meridian as shown on Figure 1. It covers an area of about, 145.8 square kilometres (Ezewanji and Orji, 2010). Enugu Metropolis comprises of three Local Government Areas namely, Enugu North, Enugu South, and Enugu East Local Government Areas. Enugu Metropolis is bounded in the north east by Isi-Uzo and northwest by Igbo-Etiti Local Government Areas, in the east and south by Nkanu East and Nkanu West Local Government Area (LGA) respectively and in the west by Udi Local Government Area as shown on Figure 1. Enugu urban has tropical wet and dry type of climate according to the Koppen's climatic classification system and experiences two seasons which are warm. Rainy season lasts between March and October and dry season between November and February being eight and four months respectively and has an average rainfall of between $1800 \mathrm{~m}$ and $2000 \mathrm{~m}$ (Anyadike, 2002). The area has a double peak regime of rainfall in the year with about eight months of heavy rainfall. That is, between March and October when monthly rainfalls generally exceeds 50mm. Due to its latitudinal location, the study area receives abundant and constant insolation. Monthly mean temperatures are uniformly high throughout the year (about $26.9^{\circ} \mathrm{C}$ ) but ranging from about $25.5^{\circ} \mathrm{C}$ in the middle of the wet season to about $29.5^{\circ} \mathrm{C}$ just before the onset of the raining season. The mean monthly maximum temperature is about $32^{\circ} \mathrm{C}$. The mean monthly minimum temperature is about $21.8^{\circ} \mathrm{C}$ but ranges generally from $18^{\circ} \mathrm{C}$ in December and January (dry season) to $24^{\circ} \mathrm{C}$ in March and April (Anyadike, 2002). 


\section{Materials and Methods}

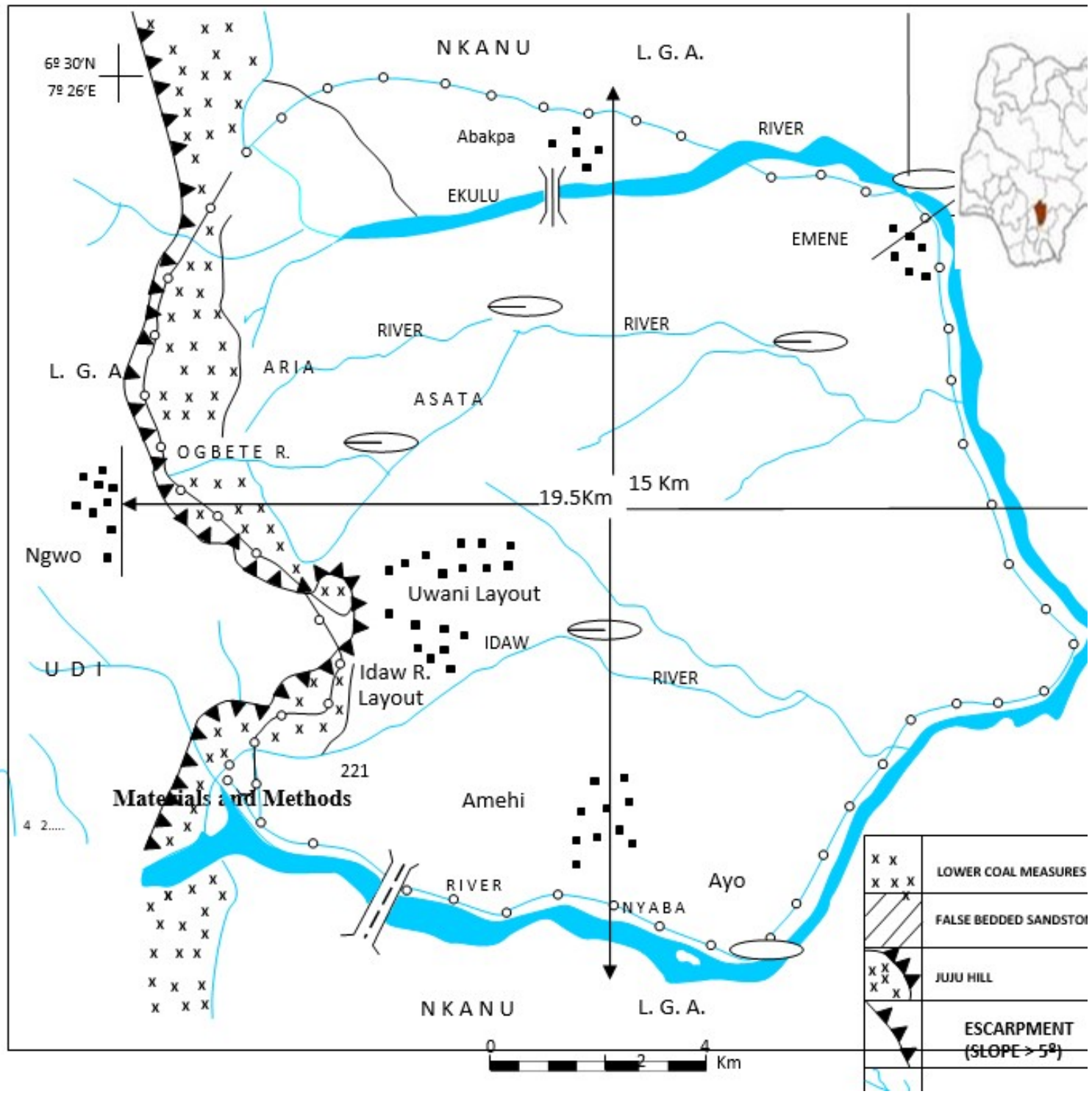

Figure 1: Enugu Metropolis:

Source: Enugu State of Lands \& Surveys, 2001

\section{Materials and Methods}

\subsection{Materials and Sampling Technique}

Water quality parameters considered in the study are turbidity, total suspended solids (TSS), iron (Fe), magnesium $(\mathrm{Mg})$, phosphate $\left(\mathrm{PO}_{4}{ }^{3-}\right)$ and total coliform count $(\mathrm{TCC})$. Samples were taken from several designated points of the river: upstream (control point)and downstream. The upstream sampling was done at Abaka, while downstream sampling was done at Emene. In each site, sampling was done at points or near points of abstraction i.e. where the Community comes to draw water. This is consistent with a well-known criterion for selecting points for sampling (Hunt and Wilson, 1986). The polyethylene wide-mouth bottles with a firm cover were used for sampling water from streams. Two millimeter of $\mathrm{HCl}$ was added to the water samples collected to prevent microbial activity. Sterilization of the bottle for microbiological was done by an electric oven or by boiling in the absent of electricity. Sampling was carried out for 12 calendar months (From October 2017 to September 2018).

\subsection{Determination of Load Flow Duration Curve}

$\mathrm{T}$ he load flow duration curve was used to estimate the available amount of water that can keep up the stream 
flow and the variability of the amount of the water in the catchment as has been stipulated by Fennessey and Vogel (1990) and Yu, Yang and Wang (2002). Flow duration curve (FDC) of River Ekulu was constructed using FDC programme developed by McCarthy (2009). To determine the pollutants load duration, the graphical method was adopted as has been previously applied by Unthank (2012). The fomular is given as:

Load $=$ Flow $* \mathrm{~T} * \mathrm{C}$

Where

Load: is the load of the applicable water-quality constituent,

Flow: is the estimated daily stream flow provided by the model (in cubic feet per second),

T: $\quad$ is the selected water-quality criterion, and

$\mathrm{C}: \quad$ is a multiplication factor to ensure unit consistency.

By displaying instantaneous loads calculated from ambient water quality data and the daily average flow on the date of the sample, Load duration curve graphs of selected pollutants were developed, which describes the characteristics of the water quality impairment. Loads that plot above the curve indicate an exceedance of the water quality criterion, while those below the load duration curve show compliance. A "margin of safety" (MOS) value of $10 \%$ was used in this study to account for uncertainties in the gauged flow data.

\subsection{Analysis of Samples:}

The water analysis was done according to standard methods by American Public Health Association (APHA) and American Water Works Association (AWWA) (2005) as follows;

i. Determination of Turbidity: This was determined in-situ using a standardized Hanna H198703 Turbidimeter. The samples were poured into the measuring bottle and the surface or the bottle was wiped with silicon oil. The bottle was then inserted into the turbidimeter and the reading was obtained and recorded in Nephelometer Turbidity Units (NUT).

ii. Determination of Total Solids (TSS) by Gravimetric method: This is obtained by a simple subtraction method. The total solid was first determined and the total dissolved solid obtained was subtracted from it. The total solid was obtained by gravimetric method: $10 \mathrm{ml}$ of the samples was measured into a pre-weighed evaporating dish which was oven dried at a temperature of $103^{\circ} \mathrm{C}$ to $105^{\circ} \mathrm{C}$ for two and half hour. The dish was cooled in a desiccator at room temperature and was weighed. The total solid was represented by the increase in the weight of the evaporating dish.

$$
\text { Total Solid }=\frac{(W 2-W 1) m g x 1000}{\text { Mlof sampleused }}
$$

Where W1 = initial weight of evaporating dish

W2 = Final weight of the dish (evaporating dish + residue)

iii.. Determination of iron and magnesium: To assess the levels of the iron, a portion of all the water samples (50 $\mathrm{ml}$ ) were initially subjected to fixing using concentrated nitric acid and concentrated hydrochloric acid in a ratio of 1:10 respectively. This was done in order to digest particulate matter inside the sample by heating carefully in a water bath to obtain thick yellow solution, and later was cooled and made up to $100 \mathrm{ml}$ with distilled water. After this fixing, the samples were directly analyzed using the Bulk Scientific AAS. JENWAY 6310 spectrophotometer and JENWAY PFP-7 flame photometer was used to determine magnesium.

iv. Determination of Phosphate: Water and Sulfuric Acid was added to a $50 \mathrm{ml}$ flask and swirled; then Ammonium Persulfate was added and boiled. Sodium hydroxide was added. The flask was swirled until faint pink colour is produced. Sulfuric acid was then added until the pink colour disappeared. The solution diluted using deionized water. Phosphate Acid Regent was added and mixed and the test tube placed in the phosphate comparator with Axial. The sample colour was matched to a colour standard and the result recorded in $\mathrm{mg} / \mathrm{l}$.

v. Determination of Total Coliform Count (Using MacConkey broth): The multiple tube technique (MTT) was employed and the 3 tube method was used. All tubes were incubated at a temperature of $37^{0} \mathrm{C}$ for $24 \mathrm{hrs}$ after which tubes showing colour changes (acid production) were regarded as positive tubes while those without a change in colour were discarded. The Magady Statistical Table was then used to get the value for the Most Probable Number (MPN) per 100ml and recorded.

\section{Results and Discussion}

The selected physicochemical and microbial parameters levels were observed to be generally high and above World Health Organisation (WHO) permissible limit for drinking water. Highest levels were recorded in July and August for turbidity and Total suspended solids, August and May for Fe and Mg and August for phosphate $\left(\mathrm{PO}_{4}{ }^{3}\right.$ )and total coliform count respectively. Turbidity ranged from lowest value of $39.01 \mathrm{mg} / 1$ to highest value of $123.5 \mathrm{mg} / 1$ with a mean value of $84.6 \mathrm{mg} / \mathrm{l}$. The high turbidity level suggests particles suspended or dissolved in water that scatter light, making the water appear cloudy or murky. Particulate matter can include sediment - 
especially clay and silt, fine organic and inorganic matter, soluble coloured organic compounds, algae, and other microscopic organisms (Boyde, 2000).

The extremely high turbidity observed during the dry season may be due to decrease in the rate of water circulation hence it takes a longer time for the highly concentrated effluents to be diluted during the dry season. High turbidity can significantly reduce the aesthetic quality of lakes and streams, having a harmful impact on recreation and tourism (Gandaseca, 2014). It can also increase the cost of water treatment for drinking and food processing as observed by Horne and Goldman (1994). Sharma, Pandey, Raghuvanshi and Shukla (2015) also observe that it can harm fish and other aquatic life by reducing food supplies, degrading spawning beds, and affecting gill function). Mean values of $143.6 \mathrm{mg} / 1$ and $142.2 \mathrm{cfu} / 100 \mathrm{ml}$ were recorded for total suspended solids and total coliform count (TCC) respectively. TSS recorded lowest to highest values of $127.5 \mathrm{mg} / 1$ to $166.5 \mathrm{mg} / 1$ respectively. Lowest to highest TCC values were recorded as $95 \mathrm{cfu} / 100 \mathrm{ml}$ and $270 \mathrm{cfu} / 100 \mathrm{ml}$ as shown on Table 1. The high levels of TSS and TCC may be due to the continuous discharge of effluents from the commercial and residential land uses which carry many materials from the catchment area into the River and since the rate of circulation is lower during dry season, this material concentrate during dry season. Bilotta and Brazier (2008) are of the view that these fine particles sometime act as food source for filter feeders which are part of the food chain, leading to biomagnification of chemical pollutants in fish and, ultimately, in man. Thus, Sharma, et al (2015) stressed that in most river basins where erosion is a serious problem, suspended solids can blanket the river bed, thereby destroying fish habitat. Also, pathogens are often clumped or adherent to suspended solids in water. TSS and TCC is partly a function of discharge because it increases with increase in discharge.

Mean levels of Fe and $\mathrm{Mg}$ were recorded as $1.2 \mathrm{mg} / 1$ and $4.2 \mathrm{mg} / 1$ respectively and both exceeded the WHO permissible limit for drinking water. The high levels of $\mathrm{Mg}$ and $\mathrm{Fe}$ concentration may be attributed to anthropogenic activities and geologic formation. Studies such as Reimann and de Caritat (1998) and Riemann de Caritat and Nsikavaan (2001) have shown that apart from natural sources, anthropogenic sources of $\mathrm{Mg}$ and $\mathrm{Fe}$ include fertilizers liming iron and steel industry, sewage and dust from iron mining. Although Fe is known to have little concern as a health hazard, it is still considered as a nuisance (stains clothes and plumbing) when available in excessive quantities (Butu, 2011). Phosphate recorded a mean value of $3.1 \mathrm{mg} / 1$ with lowest and highest values as $1.3 \mathrm{mg} / \mathrm{l}$ and $5.1 \mathrm{mg} / \mathrm{l}$. Phosphates enter water bodies from human and animal wastes, phosphaterich rocks, and wastes from laundries, cleaning and industrial processes, and farm fertilizers. The source of phosphates could be from animal wastes considering the livestock watering practices observed and sanitary facilities available in Enugu urban. Total coliform count gives a general indication of the sanitary condition of River Ekulu. The high concentration of coliform bacteria may be attributed to effluent discharge from unregulated abattoir and residential land use. This poses serious health concerns because it is an indication that there is a high possibility of the presence of harmful bacteria like E-coli, Clostridium botulinum, Campylobacter jejuni, and Vibrio cholera all of which are agents of waterborne diseases that affects human health.

Table 1: Concentration of the pollutants in River Ekulu

\begin{tabular}{|c|c|c|c|c|c|c|c|}
\hline Parameters & & Mean & SD & RANGE & MIN & MAX & "WHO \\
\hline Temp & & 28 & 0.72 & 2.2 & 27.1 & 29.3 & 25 \\
\hline $\mathrm{TSS}(\mathrm{mg} / \mathrm{l})$ & & 143.6 & 14.41 & 39 & 127.5 & 166.5 & 20 \\
\hline TDS (mg/l) & & 153 & 118.27 & 329.5 & 60.5 & 390 & 250 \\
\hline Turbidity (NTU) & & 84.6 & 25.02 & 84.45 & 39.05 & 123.5 & 5 \\
\hline $\mathrm{Ph}$ & & 6.9 & 0.52 & 1.45 & 6.3 & 7.75 & $6.5-8.5$ \\
\hline $\mathrm{EC}(\mu \mathrm{s} / \mathrm{cm})$ & & 181.4 & 65.39 & 174.5 & 115.5 & 290 & 100 \\
\hline $\mathrm{Na}+(\mathrm{mg} / \mathrm{l})$ & & 118.8 & 32.07 & 85.95 & 84.05 & 170 & 250 \\
\hline $\mathrm{DO}(\mathrm{mg} / \mathrm{l})$ & & 6 & 0.42 & 1.25 & 5.25 & 6.5 & 6.5 \\
\hline $\mathrm{Ca} 2+(\mathrm{mg} / \mathrm{l})$ & & 46.4 & 14.99 & 44.1 & 26 & 70.1 & 200 \\
\hline $\mathrm{Cl}-(\mathrm{mg} / \mathrm{l})$ & & 21.7 & 7.73 & 20.95 & 12.5 & 33.45 & 250 \\
\hline $\mathrm{Fe}(\mathrm{mg} / \mathrm{l})$ & & 1.2 & 0.97 & 2.49 & 0.16 & 2.65 & 0.3 \\
\hline $\operatorname{Mg}(\mathrm{mg} / \mathrm{l})$ & & 4.2 & 2.29 & 5.45 & 1.5 & 6.95 & 100 \\
\hline $\mathrm{NO}_{3}(\mathrm{mg} / \mathrm{l})$ & & 1.8 & 1.77 & 4.25 & 0.3 & 4.55 & 10 \\
\hline $\left.\mathrm{PO}_{4}^{3-(} \mathrm{mg} / \mathrm{l}\right)$ & & 3.1 & 1.32 & 3.85 & 1.25 & 5.1 & 5 \\
\hline $\mathrm{SO}_{4}{ }^{2-}(\mathrm{mg} / \mathrm{l})$ & & 9.3 & 4.31 & 11.9 & 4.5 & 16.4 & 250 \\
\hline E.coli $(\mathrm{CFU} / 100 \mathrm{ml})$ & & 67.7 & 16.95 & 63.5 & 36 & 99.5 & 0 \\
\hline $\begin{array}{l}\text { Total } \\
\text { (CFU/100ml) }\end{array}$ & Coliform & 179.6 & 57.07 & 180 & 125 & 305 & 0 \\
\hline
\end{tabular}

Source: Fieldwork (2018) and WHO (2011)

\subsection{Flow Duration Curve Analysis}

The Flow-Duration Curve (FDC) is a graph of the stream discharge plotted against exceedence frequency and is developed by using daily stream/river data collected at the stream's gauge station downstream (Vogel and 
Fennessey,1994). FDC subdivides each of the hydrological conditions into high flows (0-15\%), another for moist conditions (15-40\%), one covering mid-range flows (40-60\%), another for dry conditions (60-85\%), and one representing low flows (85-100\%). However studies have shown that the method can be used to construct a load duration curve for predicting whether pollutants are coming from point and or diffuse sources (Eheart, Wildermuth, and Hericks,1999; USEPA, 2006; 2007; Masoud, Masound and Farshad, 2012). A load duration curve considers how flow conditions relate to a variety of pollutant sources, and therefore load duration curves can be useful in differentiating between possible loading from point and nonpoint sources. The observed loads at high to moderate flows appear to suggest that non-point sources and storm water flows are potential sources and observed loads at low flows appear to suggest direct point sources or irrigation return flows. The results of load duration curves are presented on Figures 3-12. The Figures show the pollutant load at various flow regimes. All the parameters exceeded daily load requirement. Turbidity recorded Actual Loads of 23408.2 NTU, 21717.5NTU, 19623.1NTU, 17374.4NTU, 12878.1 NTU with corresponding flow rates of $189.5 c f s, 182.5 c f s$, $164.9 c f s, 157.9 c f s$, and $143.9 \mathrm{cfs}$ were recorded at the peak of rainfall. Low flow condition yielded turbidity loads of 6697.1 NTU, 5945.9NTU, 5133.8NTU, 4422NTU and 4036.2NTU corresponding to 84.3cfs, 77.2cfs, 77.0cfs, $73.0 c f s, 70.2 c f s$ flow rates respectively. Between $10 \%-40 \%$ exceedence non-point pollution is considered to be active. The interval between $40 \%$ and $60 \%$ exceedence represents median flow as shown on Figures 3 and 4. Deterministic relationship between flow rate and turbidity load yielded $\mathrm{R}^{2}$ of $0.92(92 \%)$.
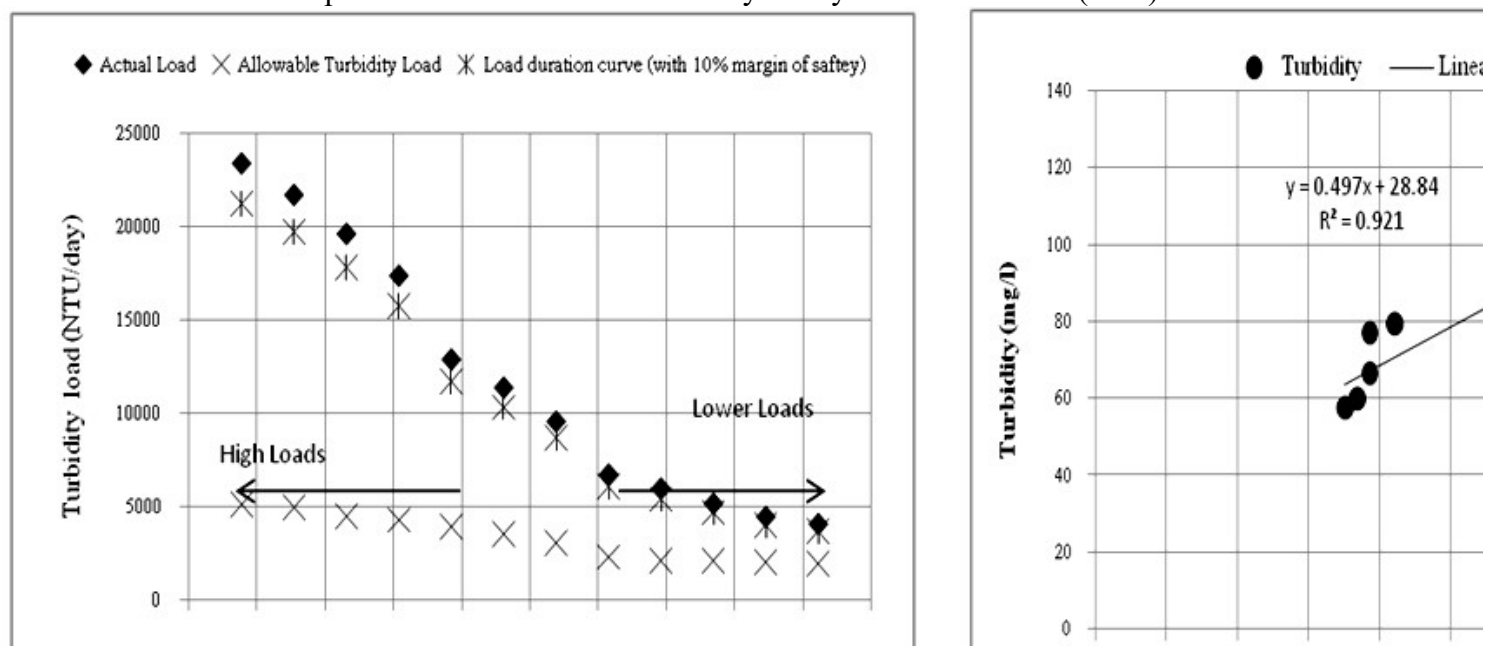

Figure 3: Turbidity Load duration curve for River Ëkulu

Figure 4: Relationship between Source; Field Work (2018)

Total suspended solids loads at the peak of rainfall were recorded as $31558.4 \mathrm{mg} / 1(189.5 \mathrm{cfs})$, $29838.8 \mathrm{mg} / 1(182.5 c f s), 26548.9 \mathrm{mg} / 1(164.9 c f s), 23771.5 \mathrm{mg} / 1(157.9 c f s)$, and $21657 \mathrm{mg} / 1(143.9 c f s)$ while low flow condition loads were $11709.4 \mathrm{mg} / 1(84.3), 10038.6 \mathrm{mg} / 1(77.2 c f s), \quad 9958.8 \mathrm{mg} / 1(77.0 c f s), \quad 9433.6(73.0 c f s)$, $89503 \mathrm{mg} / 1(70.2 c f s)$. Deterministic relationship between flow rate and TSS load yielded $\mathrm{R}^{2}$ of $0.92(92 \%)$ as shown on Figures 5 and 6.
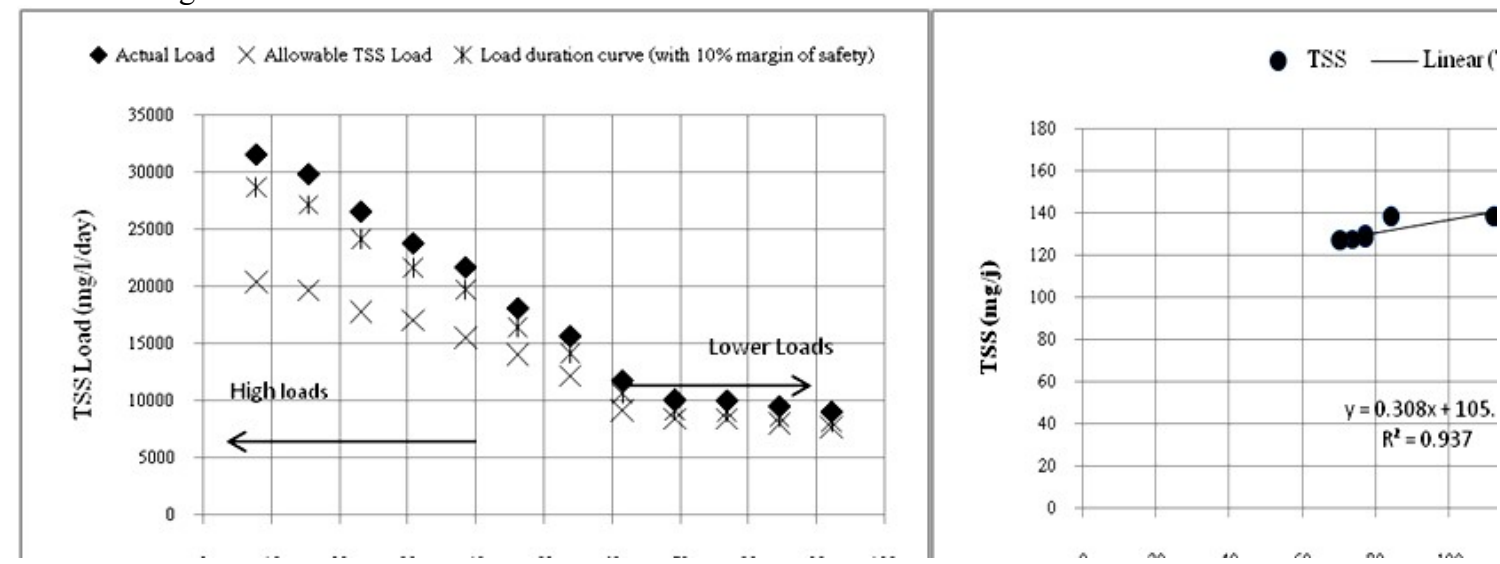

Figure 5:TSS Load duration curve for River Ëkulu Source; Field Work 2018

Iron $(\mathrm{Fe})$ loads at rainfall peak were recorded as $502.3 \mathrm{mg} / 1,459.9 \mathrm{mg} / 1,412.3 \mathrm{mg} / 1,323.8 \mathrm{mg} / 1,215.9 \mathrm{mg} / 1$ 
with corresponding flow rates of $189.5 c f s, 182.5 c f s, 164.9 c f s, 157.9 c f s, 143.9 c f s$. Low flow condition recorded Fe loads of $42.1 \mathrm{mg} / 1,38.6 \mathrm{mg} / 1,34.8 \mathrm{mg} / 1,25.8 \mathrm{mg} / 1,11 \mathrm{mg} / 12$ with corresponding flow rates of $84.3 c f s, 77.2 c f s$, $77.0 c f s, 73.0 c f s, 70.2 c f s$ as shown on Figures 7 and 8 .
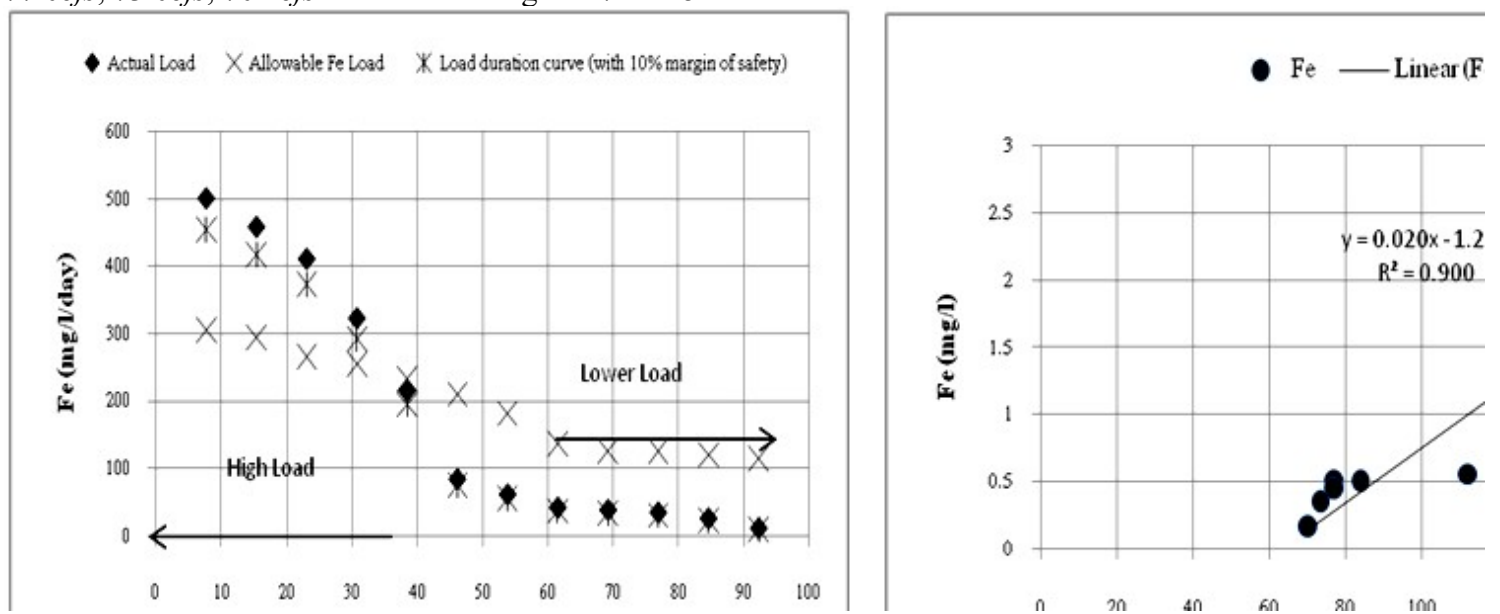

Figure 7:Fe Load duration curve for River Ekulu Source; Field Work 2018

Magnesium $(\mathrm{Mg})$ loads at the peak of rainfall were recorded as $1317.3 \mathrm{mg} / 1(189.5 c f s)$, $1268.4 \mathrm{mg} / 1(182.5 c f s), 11221.3 \mathrm{mg} / 1(164.9 c f s), 931.9 \mathrm{mg} / 1(157.9 c f s)$, and $827.4 \mathrm{mg} / 1(143.9 c f s)$ while low flow condition loads were $197.9 \mathrm{mg} / 1(84.3), 131.3 \mathrm{mg} / 1(77.2 c f s), \quad 131.1 \mathrm{mg} / 1(77.0 c f s), \quad 110.6(73.0 c f s)$, $105.3 \mathrm{mg} / \mathrm{l}(70.2 c f s)$. Deterministic relationship between flow rate and $\mathrm{Mg}$ load yielded $\mathrm{R}^{2}$ of $0.97(97 \%)$ as shown Figures 9 and 10.
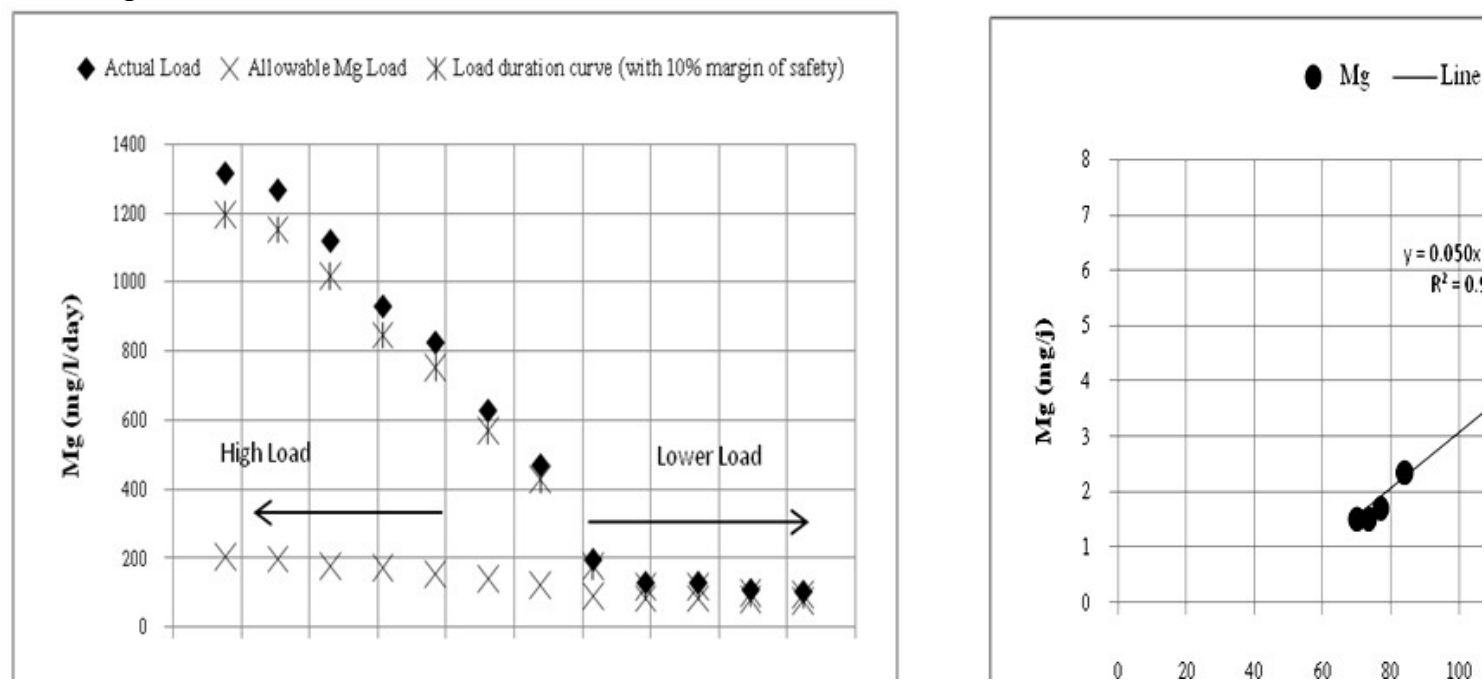

Figure 9: Mg Load duration curve for River Ekulu Source; Field Work 2018

Figure 10: Relationship between the flow rate and $\mathrm{Mg}$ load

Phosphate recorded Actual Loads of $966.7 \mathrm{mg} / 1,866.8 \mathrm{mg} / 1,758.5 \mathrm{mg} / 1,702.8 \mathrm{mg} / 1,460.8 \mathrm{mg} / 1 \mathrm{during}$ the rainfall peak while low flow condition yielded phosphate loads of $189.6 \mathrm{mg} / 1,154.4 \mathrm{mg} / 1,138.8 \mathrm{mg} / 1,103.2$ $\mathrm{mg} / \mathrm{l}$ and $87.8 \mathrm{mg} / \mathrm{l}$. The Deterministic relationship between flow and phosphate yielded $\mathrm{R}^{2}$ value of 0.95 (95\%) as shown on Figure 11 and 12. 

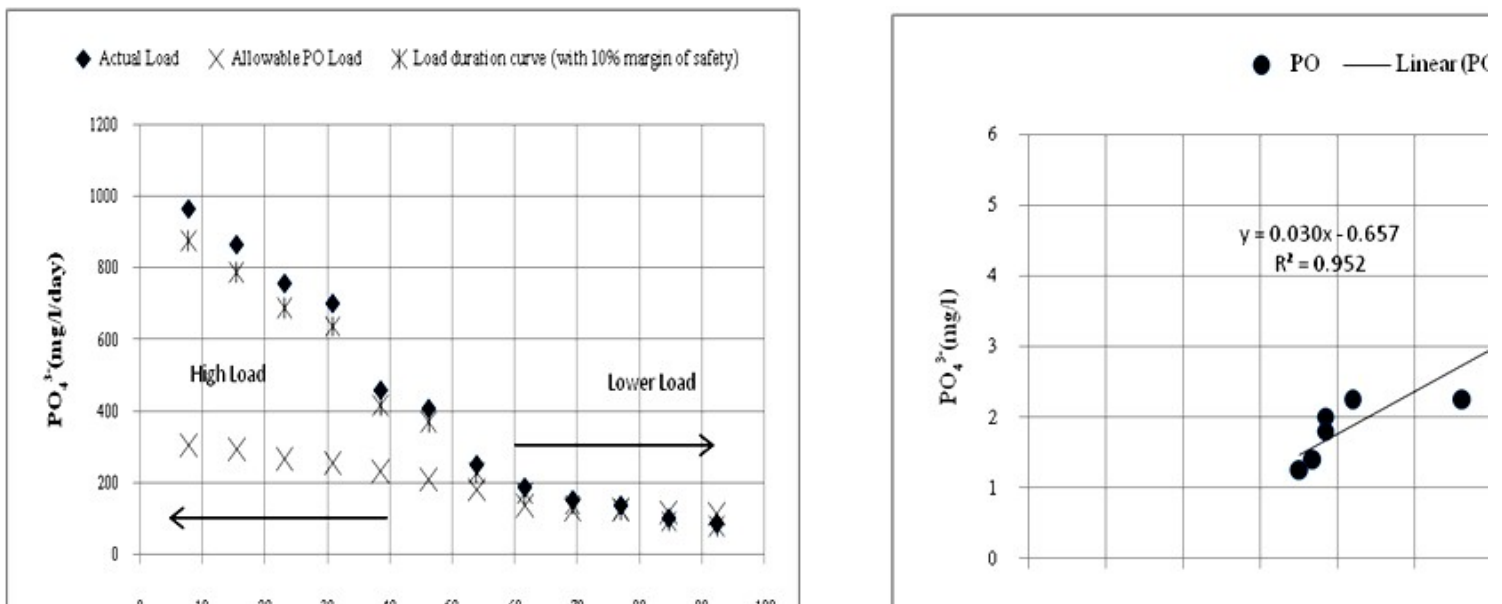

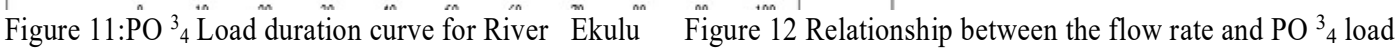
Source; Field Work 2018

Total Coliform count (TCC) loads at the peak of rainfall were recorded as $57809.7 \mathrm{CFU} / 100 \mathrm{ml}(189.5 \mathrm{cfs})$, $50187.5 \mathrm{CFU} / 100 \mathrm{ml}(182.5 c f s), 31331 \mathrm{CFU} / 100 \mathrm{ml}(164.9 c f s), 29615.6 \mathrm{CFU} / 100 \mathrm{ml}(157.9 c f s)$, and 2446.3 CFU/100ml 143.9cfs) while low flow condition loads were $12846.6 \mathrm{CFU} / 100 \mathrm{ml}(84.3), 11583 \mathrm{CFU} / 100 \mathrm{ml}$ $(77.2 c f s), 9843 \mathrm{CFU} / 100 \mathrm{ml}(77.0 c f s), 9212.5 \mathrm{CFU} / 100 \mathrm{ml}(73.0 c f s), 8775(70.2 c f s)$ as shown in Figures 13 and 14.
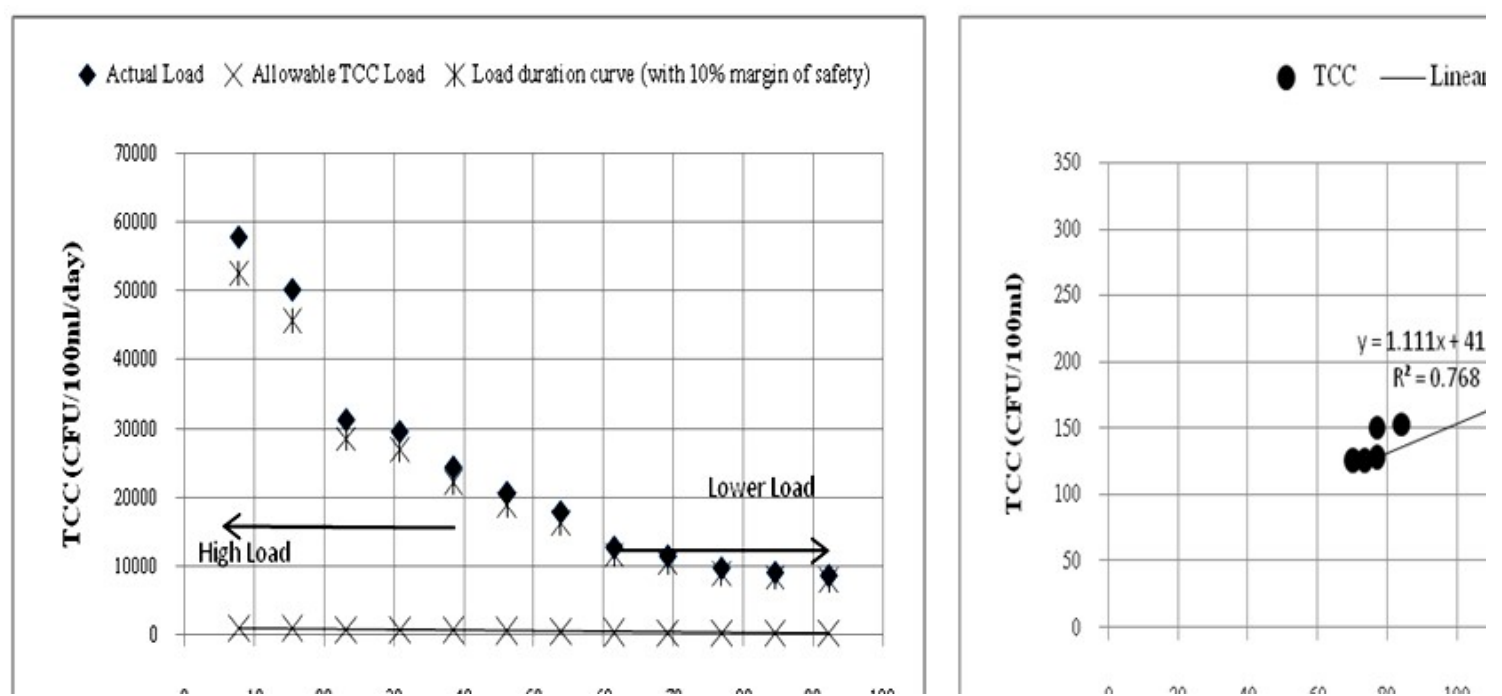

Figure 13:TCC Load duration curve for River Ekulu Figure 14: Relationship between the flow rate and TCC load Source; Field Work 2018

\section{Conclusion and Recommendations}

The paper looked at the seasonal distribution and load duration curve of selected pollutant in River Ekulu, Enugu metropolis. The study shows evidence of non- point contamination of the River Ekulu which maybe directly linked to the processes of urban growth and development of Enugu metropolis. These pollutants are mostly from sewage and industrial discharge, indiscriminate disposal of domestic waste. The situation seems to be worse during the peak of rainfall as most of these wastes and effluents are transported into the Ekulu River by storm runoff. The unregulated activities of abattoir houses, careless and indiscriminate disposal of solid waste in Enugu urban are of concern to the health of Ekulu River. The study, therefore, recommends proper waste management especially disposal systems. There is need to enact and enforce laws on effluent treatments at the sources before discharge into water bodies. Regular monitoring of activities of abattoirs by State Environmental Protection Agency for compliance with hygienic requirements and sanitary regulations governing the operations of abattoir in the country is recommended. Investors dealing with animal wastes such as manure, bone and blood should be encouraged through government policies on waste-to-resources practices.

\section{Acknowledgement}


The authors sincerely thank the field assistants that assisted in the collection of the data for this study. We are also very grateful to the members of staff of the Laboratory Unit, National Centre for Energy and Environment, University of Benin, Benn City, Nigeria that analyzed the data that is used for the study.

\section{References}

Amadi, A,N.(2010) Amadi A.N (2010). Effects of Urbanization on Groundwater: A case study of Port Harcourt, Southern Nigeria. Natural and Applied Sciences Journal,11(12):143-152

Anhwange, B.A..Agbaji, E. B and E.C Gimba (2012): Impact Assessment of Human Activities and Seasonal Variation on River Benue, within Makurdi Metropolis International Journal of Science and Technologyv, 2(5): $248-254$

Anyadike, R.N.C. (2002). Climate and Vegetation. In Ofomata, G.E.K. (ed.) A survey of the Igbo Nation.Onitsha, Africana First Publishers. pp 73-82

APHA,AWWAand WEF,(2005).Standard Methods for the Examination of Water and Wastewater 21st Edition.AmericanPublic Health Association, Washinton D.C

Boyde E.C (2000). Water quality: An introduction. Alabama Agricultural Experiment Station, Department of Fisheries and Allied Aquacultures, Auburn University, USA

Bilotta G. S. and R.E. Brazier. (2008). Understanding the influence of suspended solids on water quality and aquatic biota. Water Research 42(12): 2849-2861

Butu, A.W.(2011) Assessment of the Levels of Concentration of metal contaminations in River Kabanni, Zaria Nigeria. Unpublished Ph.D Thesis, Department of Geography Ahmadu Bello University Zaria Nigeria.

Butu, A.W. and Q.O. Sadiq (2016). Assessment of some heavy metal contaminant in River Romi, Kaduna, Nigeria. Nigerian Journal of Tropical Geography. 7(1):905-919

Butu,A.W., Bello., Atere, P.M and C.N. Emeribe( 2019). The Assessment of Heavy metals Pollution inTilapia Fish (oreochromis niloticus) Tissue from Thomos Dam, Kano State, Nigeria. Nigerian Journal of Agriculture Food and Environment, 15(2):89-103

Chadwick, M.A., Dobberfuhl, D.R., Benke, A.C., Huryn, A.D. Suberkropp, K. and J.E. Thiele. (2006). Urbanization Affects Stream Ecosystem Function by Altering Hydrology, Chemistry, and Biotic Richness. Ecological Applications. 16(5): 1796-1807

Chindah, A. Braide, C. and O. C. Sibeudu, (2004). Distribution of Hydrocarbons and Heavy metals in sediment and a crustacean (shrimps-Penaceousnotialis) from the bonny/new Calabar river estuary, Niger Delta. Ajeam-Ragae, 9: 1-14.

Diersing, N.(2009) Water Quality Frequently Asked Questions. Florida Brooks National Marine Sanctuary Kay West FL.

Eheart, J.W., Wildermuth, A.J., and E.E. Herricks, (1999). The effects of climate change and irrigation on criterion low streamflows used for determining total maximum daily loads. Journal of the American Water Resources Association, 35: 1365-1372

Emongor,.V. Nkegbe, E. Kealotswe, B. Koorapetse, I. Sankwase, S. and S, Keikanetswe, (2005). Pollution indicators in Gaborone industrial effluent.Journal of Appl Sci. 5: 147-150

Ezemonye, M.N (2009) Surface Water Quality of Enugu. Unpublished Ph.D Thesis University of Nigeria, Nsukka

Ezenwanji, E.E. and M.U. Orji, (2010). Seasonal Fluctuation of Microbiological Contaminants in an Urban Watershed: The Case of Asata River in Enugu, Nigeria. Tropical Built Environment Journal. 1(1):1-10

Ezenwaji, E.E. Eduputa, B.M and B.O Uwadiegwu (2014). Pollution of Ekulu River in Enugu. A case of Negative Human Impacts on the Environment. IOSR journal Environmental Science, Toxicology and food Technology, 8(10):83-92

Ezigbo, I and B.N Ezeanyim (1993). Environmental Pollution from Coal Mining Activities in the Enugu Area of Anambra State Nigeria. Mines, Water and the Environment. 12(1-4):53-61

Ezigbo, H.I.(1989):Groundwater Quality Problems in Parts of Imo State, Nigeria. Journal of Mining and Geology, 25(1):1-9

Fennessey, N and R.M Vogel (1990). Regional Flow Duration Curves for Ungauged Sites in Massachusetts. Journal of Water Resource.Plan.Mang. ASCE 116 (4): 530-549

Gandeseca, S., Rosli, N., Pazi, A.M.M. and C.I. Arianto (2014). Effect of land use on river water quality of Awat-AwatLawas Mangrove Forest Limbang Sarawak Malaysia. International Journal of Physical Sciences Vol. 19(17): 386-396

Gleick P.H (2012). Dirty Water: Estimated Deaths from Water-Related Diseases 2000-2020 Pacific Institute for Studies in Development, Environment, and Security • www.pacinst.org

Horne A.J, and C.R. Goldman (1994). Limnology; McGraw Hill Inc. USA

Hunt D.T.E and A.L Wilson (1986): The chemical Analysis of water (General principle and Technologies) $2^{\text {nd }}$ edition the Royal society of chemistry, London. Pp.683 
Inversin, A. (1986). Micro-Hydropower Source Book: A Practical Guide to Design and Implementation in Developing Countries.NRECA International Foundation, Washington DC, USA.

Kearns, F.R., Kelly, N.M. Carter, J.L. and V.H. Resh. (2005). A method for the use of Landscape metrics in Freshwater Research and Management.Landscape Ecology. 20:113-125

Liu L., Johnson, H..L, Cousens S.,, Perin J., Scott S., Lawn, J.E., Rudan, I., Campbell, H., Cibulskis, R., Li, M., Mathers, C. and R.E Black (2012). Child Health Epidemiology Reference Group of WHO and UNICEF. Global, regional, and national causes of child mortality: an updated systematic analysis for 2010 with time trends since 2000. Lancet. Jun 9;379(9832):2151-61

Masoud, H., Masoud, N.and S.S Farshad (2012). Effect of industrial and agricultural pollutants on the sustainability of Gavkhuni lagoon wetland ecosystem African Journal of Agricultural Research Vol. 7(20): 3049-3059

McCarthy, P. (2009).Travel times, streamflow velocities, and dispersion rates in the Yellowstone River, Montana: U.S. Geological Survey Scientific Investigations Report 2009-5261, 25

Morse, C.C., Huryn, A.D.and C. Cronan. (2003). Impervious Surface Area as a Predictor of the Effects of Urbanization on Stream Insect Communities in Maine, U.S.A. Environmental Monitoring and Assessment. 89: $95-127$.

NUPD (2004). Draft National Urban Development Policy

Ogbomida E.T and C.N Emeribe (2013). Impact of urbanization on Nwaorie and Otamiri Rivers in Owerri, Imo State, Nigeria Advances in Environmental Research, 2(2): 119-129

Omole, D.O. and J.M. Ndambuki, (2014). Sustainable living in Africa: Case of water, sanitation, air pollution and energy. Sustainability, 6(8): 5187-5202.

Osibanjo,O., Daso A P. and A M. Gbadebo (2011). The impact of industries on surface water quality of River Ona and River Alaro in Oluyole Industrial Estate, Ibadan, Nigeria African Journal of Biotechnology. 10 (4): 696-702

Paul, M.J.and J.L. Meyer. (2001). Streams in the urban Landscape. Annual Review of Ecology and Systematics. 32: 333-365

Porcella, D.B.and D.L. Sorenson. (1980). Characteristics of Nonpoint Source Urban Runoff and its Effect on Stream Ecosystems. EPA 600-3-80-032.

Reimann C, and P. de Caritat (1998). Chemical elements in the environment factsheets for the geochemist and environmental scientist. Berlin, Germany Springer-Verlag

Reimann C, Kashulina G., de Caritat and H. Niskavaara (2001). Multielement, multi-medium regional geochemistry in the European arctic: element concentration, variation and correlation. Applied Geochemistry 16:759-80.

Schueler, T.R. (1992). Mitigating the Adverse Impacts of Urbanization on Streams: A ComprehensiveStrategy for Local Governments, In: P. Kumble and T. Schueler, (Eds.), Watershed restoration sourcebook, Metropolitan Council of Governments, College Park, Maryland, USA, pp. 21-31.

Sharma P.K., Pandey R., Raghuvanshi, D and D.N. Shukla (2015). Assessment of physicochemical Parameters to investigate pollution status of River Ganga at Haridwar, Uttarakhand, India. Asian Journal of Biochemical and Pharmaceutical Research Vol 5 (4) 170-176

Sponseller, R.A., Benfield, E.F. and H.M. Valett. (2001). Relationships between Landuse, Spatial scale and Stream Macroinvertebrate Mommunities. Freshwater Biology. 46: 1409-1424

United States Environmental Protection Agency (USEPA), (2007). Options for Expressing Daily Loads in TMDLs. EPA Pub.No. 841-B-07-006.68 p.

USEPA. (2006): An Approach for Using Load Duration Curves in Developing TMDLs. U.S. Environmental Protection Agency, Office of Wetlands, Oceans and Watersheds, Washington, DC.

Unthank, M.D., Newson, J.K., Williamson, T.N., and H.L. Nelson (2012). Construction of estimated flow- and load-duration curves for Kentucky using the Water Availability Tool for Environmental Resources (WATER): U.S. Geological Survey Scientific Investigations Report 2012-5168, 14 p., at http://pubs.usgs.gov/sir/2012/5168/

Voelz, N.J., Zuellig., R.E., Shieh, S.H. and J.V. Ward. (2005). The Effects of Urban Areas on Benthic Macro invertebrates in two Colorado Plains Rivers. Environmental Monitoring and Assessment. 101: 175-202.

Vogel, R.M., and N.M. Fennessey, (1994). Flow-Duration Curves. New Interpretation and Confidence Intervals.Journal of Water Resources Planning and Management, 120(4): 485-504.

Walsh, C.J., Sharpe, A.K. Breen, P.F. and J.A. Sonneman. (2001): Effects of Urbanization on Streams of the Melbourne Region, Victoria, Australia: Benthic macroinvertebrate communities. Freshwater Biology. 46: 535-551.

Walsh, C.J. (2006). Biological Indicators of Stream health Using Macroinvertebrate Assemblage Composition: A Comparison of Sensitivity to an Urban gradient. Marine and Freshwater Research. 57:37-47.

World Health Organization-WHO (2011). Guidelines for Drinking Water Quality. Vol II, $4^{\text {th }}$ Ed, Geneva. 
Yu, P., Yang, T. and Y. Wang (2002). Uncertainty Analysis of Regional Flow Duration Curves. Journal of Water Resources Planning and Management, 128: 424-430.

\section{The Authors}

*Dr Ali Williams Butu holds PhD in Geography (Hydrology and Water Resources Management) from Ahmadu Bello University Zaria, Nigeria. He is currently an Associate Professor of Geography and Head of Department of Geography Nigerian Army University Biu, Nigeria.

* Dr Nchedo Nnedima Ubachuckwu holds PhD in Geography (Environmental Management) from Nigerian Defence Academy Kaduna, Nigeria. Currently she teaches Geography at the Nigerian Tulip International College Abuja, Nigeria.

* Dr chukwudi Nnaemeka Emeribe holds PhD in Geography (Hydrology and Water Resources ) from the University of Benin, Benin City Nigeria. He is currently a Principle Research Fellow at National Centre for Energy and Environment, Energy Commission of Nigeria, University of Benin, Benin City, Nigeria.

*Dr Aliyu Dadan-Garba holds PhD in Hydrology and Water Resources Engineering at University of Surrey, UK. $\mathrm{He}$ is currently a Senior Lecturer in the Department of Geography Nigerian Defence Academy Kaduna, Nigeria. *Dr Abdullahi Abubakar Bichi holds PhD in Geography (Hydrology and Water Resources Management) from Ahmadu Bello University Zaria, Nigeria. He is currently a Senior Lecturer in the Department of Geography Federal University Gusau, Nigeria. 